\title{
AOR
}

Selected Papers of \#AolR2020:

The $21^{\text {st }}$ Annual Conference of the

Association of Internet Researchers

Virtual Event / 27-31 October 2020

\section{BULLYING IN CON/FFLATING SPACES - WHY A 'SPACE' PERSPECTIVE MATTERS FOR UNDERSTANDING YOUNG PEOPLE'S EXPERIENCES AND PRACTICES OF BULLYING}

\author{
Tabea Bork-Hüffer \\ University of Innsbruck \\ Belinda Mahlknecht \\ University of Innsbruck \\ Katja Kaufmann \\ University of Innsbruck
}

One of the risks children and adolescents increasingly have to face in their digitally connected lives is bullying. However, their bullying experiences and practices as well as the larger socio-material-technological contexts into which these are embedded, are not confined to the virtual sphere, but occur in variegated inseparable and conflating spatialities. Thus, it is all the more urgent for the often disparate areas of research on traditional bullying and cyberbullying to not only take note of each other, but also to analyse the interdependences, intersections and conflation of bullying in digital and offline spaces in a more comprehensive manner. In our view, more recent conceptualisations of 'space' offer valuable contributions to a reflection upon the epistemological and related methodological considerations when seeking to understand the lifeworlds, practices and experiences of young people involved in bullying. In this sense, we have recently advanced the concept of "cON/FFlating situational spaces and places" (Bork-Hüffer and Yeoh 2017: 93) in an attempt to integrate existing algorithmic, (post-)feminist and relational perspectives to the analysis of bullying (cf. Bork-Hüffer et al. 2020).

Meanwhile, existing studies are mostly quantitative in nature, with an emphasis on structures and conditions, and split into studies looking at traditional offline (e.g., Woods and Wolke 2004; Stassen Berger 2007) or cyberbullying (Willard 2007; Schultze-

Suggested Citation (APA): Bork-Hüffer, T., Mahlknecht, B. \& Kaufmann, K. (2020, October). Bullying in cON/FFlating Spaces - Why a 'Space' Perspective Matters for Understanding Young People's SocioMaterial-Technological Experiences and Practices of Bullying. Paper presented at AolR 2020: The 21 Annual Conference of the Association of Internet Researchers. Virtual Event: AolR. Retrieved from http://spir.aoir.org. 
Krumbholz et al. 2012; Betts 2016). These perspectives have thus taken either a focus on socio-material or techno-social contexts of bullying. Only more recently, some works have started to bridge both spheres by looking into the similarities and differences of traditional and cyberbullying (e.g., Antoniadou and Kokkinos 2015).

What still remains unexplored in these, predominantly quantitative, studies are young people's subjective perspectives and their everyday experiences of the intersecting and conflating spaces that are critical to understanding how bullying unfolds among young people. In line, we applied a young people-centred approach that used written narratives produced by young adults in Austria with the objective to let them speak with their own voice when describing their experiences and involvement with (cyber)bullying (Bork-Hüffer et al. 2020). We asked: Whether and how does bullying in physical and digital spaces intersect in school contexts?

Our study showed how the continuous technological advancement of not only the digital devices but also of the affordances of specific media used, played a fundamental role in the historicity of bullying in the young adults' lives: In the opportunities for, types of, frequencies and harshness of bullying attacks. Kitchin and Dodge (2011: 4) have elaborated the contingent, ontogenetic and performative function of hard- and software in the co-construction of space, stating that "coded objects, infrastructures, processes, and assemblages mediate, supplement, augment, monitor, regulate, facilitate, and ultimately produce collective life.". Our results reflect how particularly with the increasing appropriation of smartphones as "digital companions" (Thulin et al. 2020: 170) cyberbullying attacks became omnipresent in all spaces of young adults' lives (cf. also Slonje and Smith 2008). What is more, when a combination of digital media, acting as integrated and converged set (cf. Madianou and Miller 2013) became used, digital media turned into "(poly-)mediators" (Bork-Hüffer et al. 2020: 7) of the attacks.

However, as Rose (2017: 799) remarks, given the dominant focus on the technological and more-than-human in recent conceptualisations of space, the "agency of the human, [...] has been left undertheorized". In our study, perpetrators of bullying were among our respondents, and their accounts laid bare the relevance of human individual and collective agency in intentional and reflected acts of bullying - regardless of the acts being enabled and channelled through affordances of hard- and software. Often, (co-) perpetrators precisely did not act anonymously but were part of the target's peer groups. Here, Elwood (2020: 3) argues that "digital objects, praxes and ways of knowing always contain possibilities for unanticipated forms of agency, subjectivity, or sociospatial relations." Indeed, the making of relational space by people, their conflictive interactions and practices, its historicity and the role of power, are central to understanding bullying in cON/FFlating spaces. Our study showed the relevance of deeply ingrained heteronormative discourses in Austrian society that were reflected particularly in gendered and partly intersectional bullying.

Even when bullying practices themselves seemed to be restricted to digital spaces, they are still entangled within the spatialities of participants' relations, practices, identities and life-worlds that stretch across inseparable socio-material and technological spheres. Thus, they are characterised by cON/FFlating spaces of bullying even if not by cON/FFlating practices of bullying per se. Bullying practices that were performed only 
online, strongly encroached into pupils' public offline spaces at school and private home space in the evenings. Although bullying has reached an anytime-anywhere quality, in our study in schools, it remained somewhat localised, occurring in the social connections and entity of the class groups.

\section{References}

Antoniadou, N., and Kokkinos, C. M. (2015). Cyber and School Bullying: Same or Different Phenomena. Aggression and Violent Behavior 25: 363-372. doi:10.1016/j.avb.2015.09.013.

Betts, L. R. 2016. Cyberbullying: Approaches, Consequences and Interventions. London: Palgrave Macmillan.

Bork-Hüffer, T., and B. Yeoh. 2017. "The Geographies of Difference in Conflating Digital and Offline Spaces of Encounter: Migrant Professionals' Throwntogetherness in Singapore." Geoforum 86 (11): 93-102.

Bork-Hüffer, T., Mahlknecht, B. and K. Kaufmann (2020): (Cyber)Bullying in Schools When Bullying Stretches Across cON/FFlating Spaces. Children's Geographies. Online first. doi:10.1080/14733285.2020.1784850

Elwood, S. (2020). Digital geographies, feminist relationality, Black and queer code studies: Thriving otherwise. Progress in Human Geography. Online first. doi:10.1177/0309132519899733

Kitchin, R., \& Dodge, M. (2011). Code/space: software and everyday life. London, Cambridge: MIT Press.

Madianou, M., \& Miller, D. (2013). Polymedia: Towards a new theory of digital media in interpersonal communication. International Journal of Cultural Studies 16 (2): 169-187. doi:10.1177/1367877912452486

Rose, G. (2017). Posthuman Agency in the Digitally Mediated City: Exteriorization, Individuation, Reinvention. Annals of the American Association of Geographers 107 (4): 779-793. doi:10.1080/24694452.2016.1270195

Schultze-Krumbholz, A., A. Jäkel, M. Schultze, and H. Scheithauer. 2012. "Emotional and behavioural problems in the context of cyberbullying: a longitudinal study among German adolescents." Emotional and Behavioural Difficulties 17 (3-4): 329-345. doi:10.1080/13632752.2012.704317.

Slonje, R. and P. Smith. 2008. "Cyberbullying: Another Main Type of Bullying." Scandinavian Journal of Psychology 49 (2): 147-157.

Stassen Berger, K. 2007. "Update on Bullying at School: Science forgotten?" Developmental Review 27 (1): 90-126. 
Willard, N. 2007. Cyberbullying and Cyberthreats: Responding to the Challenge of Online Social Aggressions, Threats, and Distress. Champaign: Research Press.

Woods, S., and D. Wolke. 2004. "Direct and Relational Bullying Among Primary School Children and Academic Achievement." Journal of School Psychology 42 (2): 135-155. 